\title{
COMUNICAÇÃO \& ARTE EM PERSPECTIVA ECOSSISTÊMICA E SEMIÓTICA
}

\section{COMMUNICATION \& ART IN ECOSYSTEM AND SEMIOTIC PERSPECTIVE}

\author{
Ítala Clay de Oliveira FREITAS ${ }^{1}$; Rafael de Figueiredo LOPES ${ }^{2}$
}

Resumo: O artigo apresenta pressupostos acerca da perspectiva inter e transdisciplinar de Ecossistemas Comunicacionais, reconhecendo o dinamismo e a interdependência dos acontecimentos físicos, biológicos e socioculturais. Nesse sentido propõe uma reflexão entre Comunicação e Arte, pelas dimensões do sensível e da cognição, sublinhando o caráter expressivo no entrelaçamento entre esses dois campos do conhecimento. A abordagem teórico-metodológica é feita a partir da semiótica, em diálogo-trama com aspectos da história, antropologia, processos de criação, e estudos sobre o corpo e o ambiente.

Palavras-chave: Comunicação; Ecossistemas Comunicacionais; Arte; Semiótica.

Abstract: This paper presents conjectures about the transdisciplinary perspective of Communicative Ecosystems, recognizing the dynamism and interdependence of physical, biological and socio-cultural events. Accordingly proposes a reflection of Communication and Art, the dimensions of cognition, emphasizing the links between these two fields of knowledge. The theoretical and methodological approach of semiotics, dialoguing with aspects of history, anthropology, creative processes, and studies on the body and the environment.

Keywords: Communication; Communicative Ecosystems; Art; Semiotics.

1 Doutora em Comunicação e Semiótica pela PUC-SP, diretora do Departamento de Cultura e Produção de Imagem da Universidade Federal do Amazonas, professora do Programa de PósGraduação em Ciências da comunicação da UFAM. E-mail: iclayfreitas@ hotmail.com.

2 Mestrando no Programa de Pós-Graduação em Ciências da Comunicação da Universidade Federal do Amazonas, na área de Ecossistemas Comunicacionais. Bolsista da Capes. E-mail: rafaflopes@bol.com.br. 


\section{míDiA

\section{Introdução}

Este artigo propõe uma aproximação ecossistêmica entre Comunicação e Arte. Partimos de aportes teóricos acerca da proposta conceitual de Ecossistemas Comunicacionais, perspectiva emergente no campo da Comunicação, imbuída em ideias do pensamento complexo e sistêmico, que tem ganhado inúmeros desdobramentos investigativos e lastro institucional no Programa de Pós-Graduação em Ciências da Comunicação da Universidade Federal do Amazonas.

Desse modo, salientamos o caráter inter e transdisciplinar dessa abordagem, que investiga os fenômenos comunicacionais pelas interações entre o ser humano, o ambiente, a cultura e a tecnologia. Uma perspectiva que contesta pensamentos e métodos cartesianos-newtonianos e teorias clássicas da comunicação, pois não descarta as subjetividades e incertezas das circunstâncias envolvidas nos processos comunicacionais. Assim, a compreensão dos fenômenos ocorre a partir da trama relacional entre seus elementos, quebrando paradigmas de abordagens tradicionais que reduzem a complexidade comunicativa a uma dimensão funcionalista e simplificadora.

Essa ideia encontra consonância em Capra (2002) para quem a ciência precisa ser sustentável, redefinida na relação do ser humano com a natureza, analisando os fenômenos pela integração das dimensões biológica, cognitiva e social da vida, e adotando uma visão sistêmica para enfrentar os problemas que vão da ordem do mundo prático aos questionamentos filosóficos. Ou seja, não apenas focada em fenômenos materiais, mas contemplando o que decorre do campo dos significados. Para o autor tudo está interligado por complexas redes de interconexões simbióticas, sejam elas da ordem de recombinação genética da célula de uma bactéria ou referentes ao movimento dos planetas no espaço. Por isso, defende que é preciso ter consciência

[...] que as redes metabólicas dos sistemas biológicos correspondem às redes de comunicação dos sistemas sociais; que os processos químicos que produzem estruturas materiais correspondem aos processos de pensamento que produzem estruturas semânticas; e que os fluxos de energia e matéria correspondem aos fluxos de informações e ideias (CAPRA, 2002, p. 267).

Dessa forma, segundo Capra (2002), a comunicação e a criatividade são inerentes aos sistemas vivos e às dinâmicas dos fenômenos biológicos e físicos, o que também se 


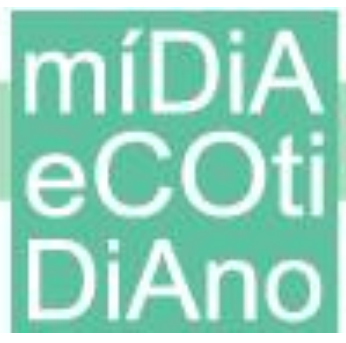

aplica ao universo cultural. De acordo com Capra (2002), imerso em ideias do neurobiólogo Humberto Maturana, a comunicação não é simplesmente transmissão de informação, mas a coordenação de comportamentos por meio de acoplamentos estruturais mútuos entre organismos vivos. O que, conforme o autor, pode ser exemplificado desde a comunicação na microbiologia celular; passando pela organização das abelhas; o canto dos pássaros; as fricções intergalácticas; até as diversas linguagens da comunicação humana, decorrentes de um complexo sistema nervoso, inter-relacionado aos processos cognitivos, que se expande pelo organismo por meio de redes físico-químicas, integrando atividades mentais emocionais e biológicas.

Conforme Capra (2002) a arte também vem influenciando a sociedade em questionar os padrões do modelo científico mecanicista, principalmente, a partir do Movimento Romântico, no fim do século XVIII. Sobretudo, com a difusão de novas ideias, desde a música de Franz Schubert, da pintura de Francisco Goya e, principalmente, da literatura de Goethe, que já se referia à natureza como a forma orgânica de um todo harmonioso em seu aparente caos, e da filosofia de Immanuel Kant que compreendia a vida como um sistema integrado por muitas partes interdependentes, capazes de se reproduzir e se auto organizar, como aponta Capra (2002).

Diante disso, propomos uma discussão acerca da relação entre comunicação e arte, numa perspectiva ecossistêmica dialogando com a semiótica, com base em Lucia Santaella, destacando conceituações acerca de linguagens, representações e estéticas comunicacionais, pois compreendemos que além de uma manifestação da sensibilidade da nossa espécie, a arte é uma forma de comunicação e produção de sentidos simbólicos.

O artigo é fundamentado em estudo teórico-bibliográfico, a fim de revisar criticamente aspectos formulados acerca da proposta temática "Comunicação \& Arte". Entretanto, exploramos diferentes trilhas, experimentamos combinações e sugerimos conexões interpretativas, apontando uma possibilidade de leitura relacional. Tal concepção implicou num arranjo teórico-metodológico em movimento dialógico, como uma espiral que tangencia autores de diferentes áreas, para a melhor aproximação com 


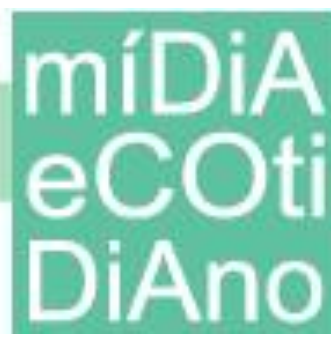

um objeto caracterizado por deslocamentos fluidos na plasticidade de suas metamorfoses espaço-temporais.

Assim sendo, instauramos uma discussão sobre a comunicação humana pelas dimensões da sensibilidade e da cognição, enfatizando relações entre corpo, mente, cultura, ambiente e seus desdobramentos em processos de criação na arte. Para isso, compomos um mosaico conceitual, embasado em noções de história, antropologia, processos criativos, ecologia profunda, filosofia e neurociência.

A trama relacional, entre diferentes campos do conhecimento, proporcionou estabelecer múltiplas conexões, sinalizando inúmeras possibilidades e arranjos que podem ser articulados numa interpretação ecossistêmica. Lembrando que a concepção de Ecossistemas Comunicacionais não tem intenção de se tornar uma nova teoria da comunicação, mas se estrutura na medida em que reestrutura seus objetos, em mutáveis relações sistêmicas e complexas, como discutiremos a seguir.

\section{Uma perspectiva ecossistêmica comunicacional}

Ao nos aproximarmos da órbita dos Ecossistemas Comunicacionais, que não se configura como um conceito formal e fechado, podemos ter a impressão de estarmos perdidos no espaço ou num bote, à deriva, na imensidão do mar. Ou ainda numa densa floresta, atentos às pistas da natureza, em busca de uma trilha que nos aponte um caminho seguro. Afinal, como é possível pensar e fazer ciência sem a coerência de uma teoria formulada, estruturada com métodos tradicionais, procedimentos práticos, resultados que garantam o rigor dos estudos? Sem a credibilidade de um selo que lhe ateste cientificidade?

Responder a esses questionamentos não é fácil, mas talvez acione o início de um pensamento em cadeia, no intuito de investirmos no empreendimento de construções que nunca serão finalizadas e mesmo assim não perdermos o prazer de continuar a edificá-las. Erguer uma ponte que não leva a outra margem do rio, mas propõe a possiblidade do rio ter uma terceira margem, ou múltiplas pontes para múltiplas margens, ou ainda arquitetar uma casa sem teto, uma universidade sem chão. Mas, ao 


\section{míDiA

pensarmos desse modo, será que as pontes serão seguras, as casas habitáveis e as universidades produzirão conhecimento?

Essas alegorias servem de metáfora para nos sugerir que não há garantias. Como já salientamos, o viés dos Ecossistemas Comunicacionais não pretende se restringir a uma teoria ou um método fechado na busca de respostas definitivas. Assim, ao denominá-lo, nos referimos como uma "ideia" ou uma "perspectiva do olhar" que permite experimentações para a construção do conhecimento pela diversidade dos saberes.

Ecossistemas Comunicacionais, no entanto, já é uma proposição institucionalizada, haja vista que é a área de concentração do Programa de PósGraduação em Ciências da Comunicação da Universidade Federal do Amazonas (PPGCCOM/UFAM) ${ }^{3}$. Iniciado em 2008, foi o primeiro Programa de Pós-Graduação na área de Comunicação do Norte do Brasil a ser aprovado pela Coordenação de Aperfeiçoamento de Pessoal de Nível Superior (Capes) ${ }^{4}$. Atualmente, suas investigações são guiadas por duas linhas de pesquisa: Redes e processos comunicacionais; e Linguagens, representações e estéticas comunicacionais.

É uma concepção que dialoga com múltiplas conceituações teóricas e campos do conhecimento, propondo articulações que rompem a linearidade pragmática de algumas teorias clássicas da comunicação, para as quais o fenômeno comunicativo se estabelece, basicamente, num processo emissor-mensagem-meio-receptor e a "comunicação só ocorre quando o receptor compreende o código da mensagem enviada", como salienta Littlejohn (1988).

Se fizéssemos a relação de uma concepção clássica da comunicação com a arte, poderíamos associar o emissor ao artista, o receptor ao observador/fruidor/espectador/ouvinte/leitor etc., e a mensagem à obra de arte, na linguagem em que se manifesta. Nesse sentido tradicional, o entendimento artístico (a comunicação) só existiria se emissor e o receptor partilhassem dos códigos, através dos

Disponível em: <http://www.ppgccom.ufam.edu.br/index.php/apresentacao> Acesso em: 18 mai. 2016.

4 Disponível em: <https://sucupira.capes.gov.br/sucupira/public/consultas/coleta/propostaPrograma/ listaProposta.jsf> Acesso: em 18 mai. 2016. 


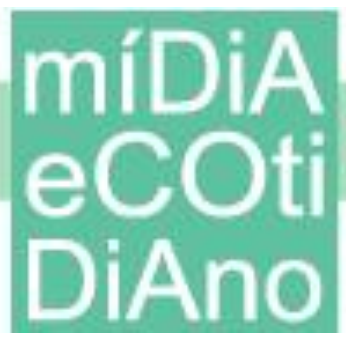

quais a mensagem fora apresentada, ou seja, só existiria comunicação se o emissor e o receptor compreendessem a linguagem da obra de arte. Entretanto, em nossa concepção, essa possibilidade é limitadora, porque exclui inúmeras outras possibilidades subjetivas e formas de percepção, interpretação e compreensão.

Os Ecossistemas Comunicacionais, portanto, seguem preceitos do Pensamento Complexo e Sistêmico, a partir de Morin (2010), compreendendo que uma teoria não é o conhecimento, nem uma chegada ou uma solução, mas uma possibilidade de partida para tratar determinado problema e só ganha vida e realiza seu papel cognitivo quando proporciona reflexão. Por isso, necessita de uma recriação intelectual permanente para conservar sua complexidade. Morin (2010) também reforça que o método não deve ser concebido como uma receita para ser aplicada de forma mecânica excluindo o sujeito de seu exercício, propondo a construção de um conhecimento relacional no intuito de evitar balizamentos reducionistas.

Segundo Morin (2002) a construção do conhecimento é um processo "auto-ecoorganizador", sempre em transformação, devido às dimensões sensíveis e cognitivas, que organizam e desorganizam a consciência sobre o que nos rodeia. Um circuito em movimento, ativando inter-relações entre os sistemas da vida, propondo um pensamento ecossistêmico, sem a separação da dimensão humana (biológica, psíquica, espiritual) da relação com seus ambientes (social, cultural, econômico, político, natural etc.).

Morin (2010) ao invés de trabalhar com uma ideia de teoria geral ou específica dos sistemas (pois para ele o holismo, que procura uma explicação dos fenômenos no nível da totalidade, é apenas uma visão simplificadora do todo), prefere a ideia de um "paradigma sistêmico". Para o autor é essencial perceber que num sistema, composto por inúmeros elementos, o todo é mais que a soma das partes e também pode ser menos que a soma das partes, ou o todo ser mais do que o todo, ou o todo ser menos que o todo, pois há um princípio hologramático de antagonismos, complementaridades e concorrências. Desse modo, as relações todo-partes são mediadas por interações e interdependências, em constantes divergências e conciliações provisórias.

Assim, devemos apoiar a ideia de sistema num conceito não totalitário e não hierárquico do todo, mas, pelo contrário, num conceito complexo da unitas 
multiplex, aberto às possibilidades. Esse preliminar paradigmático é, de fato, de importância prática e política capital. (MORIN, 2010, p. 264)

Segundo Morin (2010) a perspectiva da complexidade não deve ser concebida como uma fórmula matemática, mas como um desafio e motivação para pensar. É uma proposta que foge às ações simplificadoras e reduções mutiladoras, para promover articulações entre os diferentes tipos de conhecimentos, procurando aspirar a multidimensionalidade e ao mesmo tempo comportar em seu interior o princípio da incompletude e da incerteza. Conforme o autor a complexidade não pretende dar conta de todas as informações sobre um fenômeno estudado, mas respeitar suas dimensões, levando em consideração que "o homem é um ser biológico-sociocultural, e que os fenômenos sociais são, ao mesmo tempo, econômicos, culturais, psicológicos etc. (MORIN, 2010, p. 177).

Diante disso, quando propomos uma análise dos fenômenos comunicativos por um viés complexo, percebemos que a comunicação vai muito além da relação funcionalista entre emissor-mensagem-receptor, afinal, estamos tratando de um contexto relacional compreendido por inter-relações e interdependências. Ou seja, além da transmissão da informação há um intrincado processo de significação e compartilhamento de sentidos, com dinâmicas e ressonâncias que variam conforme as sistemáticas envolvidas.

Mesmo diante dessa configuração, possivelmente, talvez ainda pairem dúvidas sobre as ferramentas conceituais para auxiliar na compreensão dos Ecossistemas Comunicacionais, ou sobre como essa proposta se articula com outras áreas do conhecimento e como evidenciá-la em estudos teóricos e empíricos. Entretanto, como já foi ressaltado, a ideia não é aplicar uma fórmula para encontrar resultados de problemas, mas apontar pistas, trilhas e caminhos em um campo emergente da comunicação.

O que precisa estar claro é que mesmo numa aparente desordem (ou considerando a desordem como regra), existe uma sistematização com critérios científicos. Seu rigor está no vigor de aceitar que mesmo em um sistema aberto ou cambiável há critérios relevantes e recorrentes. Esse raciocínio abstrato é perfeitamente possível de ser exemplificado, por exemplo, ao pensarmos na organicidade do funcionamento do corpo humano ou no caos harmônico do universo. 
Assim sendo, o desenvolvimento da perspectiva ecossistêmica na UFAM, parte de investigações que consideram a complexidade sistêmica e informacional dos fenômenos comunicativos, "propondo estudos sobre os processos de organização, transformação e produção das mensagens conformadas na cultura a partir das interações entre sistemas sócio-culturais-tecnológicos” (MONTEIRO; ABBUD; PEREIRA, 2012, p. 09). É um campo de estudos que encontrou no contexto amazônico "um espaço emblemático para a exploração das interferências mútuas entre as diferentes esferas que regem a vida, a comunicação e a cultura" (IBID, p. 10).

É uma perspectiva em constante construção, de fluxos relacionais, e tem ganhado múltiplas propostas investigativas, a partir das diferentes visões e experiências de pesquisadores dedicados a essa "proposta aberta" da comunicação, a exemplo dos trabalhos desenvolvidos por Gilson Vieira Monteiro, fundador do PPGCCOM e de Mirna Feitoza Pereira, com pesquisas guiadas pelo viés da semiótica.

Conceitos e quadros teóricos, a exemplo da Teoria Geral dos Sistemas (Ludwig von Bertalanffy); do Pensamento Complexo (Edgar Morin); Ecologia Profunda (Fritjof Capra); Ecossistema Comunicativo (Educomunicação); Novo Sensório (Walter Benjamin); Semiosfera (Yuri Lotman); Rizoma (Gilles Deleuze e Felix Guattari); entre outros, tangenciam, inspiram e incorporam-se ao viés ecossistêmico proposto pelo PPGCCOM.

Para Colferai (2014) a Amazônia é a própria metáfora de um ecossistema comunicacional. O autor propõe uma aproximação que se articula considerando a corporeidade das relações, as tecnologias, as subjetividades sociais, culturais e o ambiente. Para desenvolver sua tese ecossistêmica, Colferai (2014) recorreu a conceitos formulados pelos biólogos chilenos Francisco Varela e Humberto Maturana, como enação, ao considerar a inseparabilidade entre ser humano e natureza, e autopoiese, ou seja, a capacidade dos sistemas vivos e suas estruturas estarem em constante autoprodução e autorregulação, mantendo interações entre seus próprios elementos e na relação com outros sistemas, além do pensamento complexo, do filósofo Edgar Morin, e da ecologia dos saberes, do sociólogo Boaventura Sousa Santos, em favor de uma ciência não paradigmática. 
Nesse sentido, Colferai (2014) defende que a comunicação se estabelece por subjetividades e materialidades efetivadas entre vivências, contradições e compreensões transitórias, pelas quais o ser humano apreende ao atuar com o meio onde se insere, muitas vezes através de acoplamentos tecnológicos ou de interfaces sensoriais, que também constituem o processo de formação cultural e codificação de linguagens.

Ter como princípio os saberes conectados implica em compreender que no Ecossistema Comunicacional não há separações entre as organizações sociais e os significados nelas postos em circulação, o ambiente físico-natural e as novas percepções e sensibilidades acionadas pela ampliação da comunicação e circulação de informações proporcionada pelas novas tecnologias. (COLFERAI, 2014, p. 59)

Desse modo, conforme Colferai (2014), embasado em Marshall McLuhan (com a ideia dos meios de comunicação como extensões do homem), há uma plasticidade favorável à conexão entre ser humano, ambiente e aparatos tecnológicos, e o que vemos, ouvimos e sentimos (seja na experiência real ou virtual, individual ou na interação social, pelas telas de TV, celulares, ipods, jogos eletrônicos etc.) provocam reações no sistema nervoso criando novas conexões neuromusculares e cognitivas, fazendo com que os aspectos biológicos, psíquicos, sociais, do ambiente e o aparato tecnológico tornem-se pontos de conexão em simbiose. É nessa dinâmica, segundo o autor, que se proporciona a expansão de corpos e sentidos, por atuações diversas e complexas. A compreensão de ecossistemas comunicacionais implica ter essa flexibilidade de entendimento e percepção e, por isso, quem se propõe a pesquisar por esse viés não deve pensar, necessariamente, em uma aplicação prática, mas exercitar a busca de multiplicidades, permitindo que a criatividade e os afetos ganhem espaço na produção do conhecimento científico.

\section{As imensuráveis dimensões da Arte}

A Arte também é comunicação e representação, além de inúmeras definições técnicas, filosóficas, estéticas, metafísicas... Antes de atribuir o caráter artístico a determinadas manifestações ou sistematizar códigos formais para a linguagem verbal ou escrita, os seres humanos já simbolizavam por gestos, dançavam, desenhavam, esculpiam, produziam sons, elaboravam construções, praticavam rituais... 
Portanto, as expressões artísticas e as formas de comunicação foram se estabelecendo nas relações com o meio, pelas possibilidades materiais e pelo desenvolvimento do processo cognoscível e da consciência reflexiva, que se transformaram ao longo do tempo e, conforme Santaella (2005), esse transcurso proporcionou a criação de linguagens para organizar o pensamento afetado pelos sentidos. Sendo assim, num lento e complexo processo, foram sendo aprimoradas a qualidade de gestos, sons, palavras, figuras simbólicas, a ativação de memórias, a relação com os outros seres e com o ambiente. Portanto, organizando diferentes combinações, códigos e linguagens, entre elas a arte. E, na arte, inúmeras linguagens artísticas.

\footnotetext{
Quando falamos em linguagem queremos nos referir a uma gama incrivelmente intrincada de formas sociais de comunicação e de significação que inclui a linguagem verbal articulada, mas absorve também, inclusive, a linguagem dos surdos-mudos, o sistema codificado da moda, da culinária e tantos outros. Enfim: todos os sistemas aos quais o desenvolvimento dos meios de reprodução de linguagem propicia hoje uma enorme difusão. [...]Isso tudo, sem falar do sonho que, desde Freud, já sabemos que também se estrutura como linguagem. (SANTAELLA, 2005, p. 11-12)
}

Logo, as linguagens são meios de comunicação e representação articuladas na imbricação de sistemas e, consequentemente, desencadeando novos processos de representação, ou processos sígnicos. Santaella (2001) traz da fenomenologia um questionamento importante: como se dá a apreensão e compreensão do mundo pelo ser humano? Segundo a autora, embasada na semiótica de Peirce, não há pensamento sem signos, que por sua vez dependem de uma interpretação para existirem, e isso ocorre pela qualidade do sentimento, ação e reação, e mediação. De acordo com Santaella (2003) o ser humano só concebe o mundo porque de alguma forma o representa e, consequentemente, só interpreta tal representação por meio de outra representação. Esse processo, pode ser gerado a partir de imagens mentais ou palpáveis, pelo gestual, por ações, sons, palavras, sentimentos etc.

No percurso signo-significação-representação, segundo Santaella e Nöth (1999), tudo o que se apresenta às percepções e ao intelecto, de forma material ou em pensamento, pode ser signo. A ação do signo, ou seja, a semiose, proporciona uma 


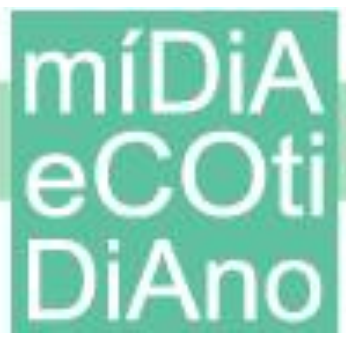

significação que vai gerar uma representação. Isto é, o signo representa a ideia de uma coisa e não a coisa em si.

Essa concepção pode ser melhor compreendida pela relação triádica da semiótica peirceana, que se constitui na triangulação signo-objeto-interpretante, de acordo com Santaella e Nöth (1999). O signo representa alguma coisa para alguém, criando em sua mente um signo equivalente. Nessa operação, gera-se um interpretante e aquilo que o signo representa é denominado seu objeto.

Portanto, a representação ou o processo representativo caracteriza-se pela interrelação entre signo-objeto-interpretante. Assim, conforme Santaella e Nöth (1999), os pensamentos se processam por meio de signos continuamente, fazendo com que as dimensões da cognição, da comunicação e da representação relacionem-se numa cadeia infinita de semiose.

Para aproximar essa ideia do campo da Arte, podemos começar imaginando uma volta aos tempos pregressos, por meio de um exercício arqueológico da história antropológica, sobretudo, pela análise e compreensão de fragmentos do passado que nos foram legados pela perpetuação de registros visuais. Conforme Prous e Ribeiro (2007) os vestígios evidenciados nos artefatos e pinturas rupestres de milhares de anos atrás, em sítios arqueológicos espalhados pelo mundo, possibilitam estabelecer possíveis significados e correlações, mas é praticamente improvável atribuir certezas para um contexto tão complexo. Acredita-se que os registos pré-históricos feitos antes da invenção da escrita, com a representação discursiva-visual de cenas cotidianas (de caça, guerra, dança, sexualidade etc.) ou simbologias míticas (concepções sobre a vida e a morte, por exemplo), por meio de desenhos ou ilustrações figurativas, manchas ou traços, estavam relacionados à consciência mágica da realidade e fins ritualísticos (PROUS; RIBEIRO, 2007).

Nesse sentido, tais registros ("origens das artes visuais"), além de configurarem-se por processos sensórios-cognitivos, em função da presença humana nos mais diversos ambientes e contextos para sua produção e percepção, constituem-se como um sistema de grande importância do ponto de vista histórico, social, cultural e artístico, estabelecendo um arco espaço-temporal-comunicativo que conecta desde as pinturas 


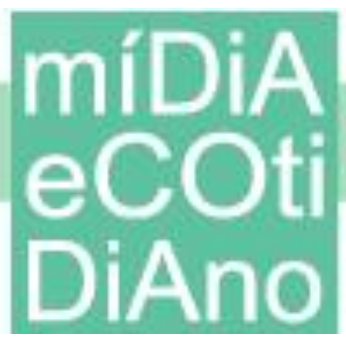

rupestres realizadas por nossos ancestrais aos grafites e pichações da paisagem urbana contemporânea, pois a arte carrega memórias em metamorfose desde tempos imemoriais.

O tempo e os símbolos que distanciam historicamente as diversas apropriações dos espaços e suportes, podem configurar diferentes significados conforme os momentos evolutivos da espécie, além da gama de diferenças culturais e interesses que se expandiram e modificaram-se ao longo dos séculos. Todavia, mantém uma ligação fundamental e universal que é a necessidade de expressão, seja para manifestar a interpretação da experiência vivida ou imaginada, para perpetuar conhecimentos e informações, pela fruição, transgressão ou quaisquer outras possibilidades que se convergem para a vontade de comunicar, que é um comportamento interativo por natureza. A arte é e sempre foi um dos principais elementos da comunicação humana, como aponta Littlejohn (1988, p. 18), que amplia ainda mais a discussão ao enfatizar que "a arte é um processo de descoberta e um caminho muito pessoal para a verdade".

Refletir sobre teorias e conceitos a respeito da arte é um exercício que exige paciência e despojamento. Janson (1996) explica que a palavra "arte" do latim ars corresponde ao termo grego téchne, ambos podem ser traduzidos como as técnicas ou os meios para se criar, fabricar ou produzir algo, o que pressupõe atividades submetidas a regras e, portanto, do ponto de vista semântico em oposição ao natural, livre e espontâneo. Entretanto, segundo o autor, na contemporaneidade, arte é um conceito subjetivo e gasoso, pois varia tanto na forma de ser produzida quanto na forma de ser interpretada, resultando de percepções culturais, valores e anseios humanos.

Mediada entre percepções, emoções e ideias, a arte é uma das manifestações humanas mais complexas no processo de produção de sentidos. É subjetiva e acompanha o nosso "trajeto antropológico", conforme Paes Loureiro (2007), ao repercutir ideias de Gilbert Durand, enfatizando que a arte é uma inquietação que nasceu de concepções mágicas e ritualísticas, passando por inúmeros contextos sociais, políticos, de interesses econômicos, ideológicos, de experimentações poéticas, e está sempre em transformação. 
De modo que não pode ser lida e compreendida de forma linear, como se a memória, o imaginário e a cultura não fossem aspectos fundamentais na constituição de linguagens simbólicas. Paes Loureiro (2007), inclusive, considera que a cultura é um meio de significação da arte.

\section{É matéria em que o artista modula sua criação, uma vez que por meio dessa ambiência criada é que o homem vive e transvive a realidade. $\mathrm{O}$ real nos coloca diante da objetividade prática de viver. $\mathrm{O}$ imaginário nos garante as aventuras de sonhar. (PAES LOUREIRO, 2007, p. 17)}

A arte é um tema amplo e complexo para ser explorado, a julgar pelo universo da música, da literatura, da pintura, entre outras expressões, portanto, vamos tratá-la de forma contextual, pois a intenção desta comunicação não é o aprofundamento epistemológico-teórico. Entretanto, ao abordarmos aspectos dessa complexa atividade humana, tecida por fios da razão e da sensibilidade, da insensatez e da rebeldia, do poder e da alienação, do sacro e do profano, do visível e do invisível, precisamos compreender que as concepções sobre manifestações artísticas, representadas em inúmeras linguagens, ao logo da história da humanidade, foram sofrendo alterações e ressignificações.

No senso comum, expressões como pintura, arquitetura, escultura, paisagismo, moda, design, decoração, teatro, cinema, dança, etc., podem ter apenas o objetivo de ser "agradável aos olhos", proporcionando prazer ou fruição estética. Porém, a potencialidade da arte e da estética é bem mais complexa, na medida em que a estese afeta diferentes níveis perceptíveis e emocionais, extrapassando simplificações sobre o belo ou o feio. Santaella (2007) diz que "cabe à estética, concebida num sentido muito mais vasto que o de uma teoria do belo, descobrir o que deve ser o ideal supremo da vida humana" (SANTAELLA, 2001, p. 38).

Portanto, há um amplo panorama a ser percorrido para compreender que a arte envolve aspectos da dimensão humana, de contextos históricos e socioculturais, interesses políticos e econômicos, aperfeiçoamentos tecnológicos e mobiliza transformações paradigmáticas. No campo da semiótica, segundo Santaella (2001), a arte é uma linguagem polissêmica, ou seja, de inúmeras linguagens e estéticas, que traz características tanto das percepções do mundo físico quanto das elaborações mentais. 
Portanto, é uma ação sígnica mediada, não é mera reprodução ou equivalência do juízo perceptivo, mas uma espécie de tradução conceitual que adquire forma (seja figurativa, simbólica ou abstrata), conteúdo e subjetividades a partir do meio e dos suportes materiais nos quais é representada. A exemplo da gravura, do grafite, da fotografia, da ópera, do cinema e assim por diante, que apresentam peculiaridades em seus contextos e aparatos. Conforme Santaella (2001), a não linearidade dos nossos processos cognitivos em sua evolução histórica, desdobrados a partir das combinações e misturas entre diferentes linguagens, faz com que "as camadas da criação humana vão se superpondo, formando um agregado cada vez mais espesso em processo de crescimento vetorizados para a complexidade" (SANTAELLA, 2001, p.95).

Desse modo, compreender e interpretar implica em traduzir signos em outros signos, num movimento inter-relacionado e ininterrupto do pensamento. Esse fluxo, de signos em transformação, carrega linguagens artísticas reconfiguradas e ressignificadas no tempo e no espaço. Paes Loureiro (2007) denomina de "conversão semiótica" o ponto de encontro ou momento de fusão pelo qual objetos, sujeitos, situações culturais ou ideias se reorganizam.

\footnotetext{
O homem cria, renova, interfere, transforma, reformula, sumariza ou alarga sua compreensão das coisas, suas ideias, por meio do que vai dando sentido à sua existência. A diversidade dinâmica real e simbólica de suas relações com a realidade exige uma compreensão também dinâmica e diversa dessas relações. (PAES LOUREIRO, 2007, p. 11)
}

A partir da capacidade de relacionar, segundo Paes Loureiro (2007), o ser humano observa o mundo e o transforma, construindo e reconstruindo relações simbólicas. No caso das artes, ao mesmo tempo em que essa linguagem polissêmica carrega camadas simbólicas e subjetivas também apresenta variáveis físicas.

Conforme Paes Loureiro (2007), ao simbolizar, ou seja, ao representar ou exprimir simbolicamente, o ser humano renova e desenvolve as relações com a realidade.

O próprio Leonardo da Vinci, no Renascimento, refere-se a essa capacidade simbolizadora do olhar, quando indica que a mente humana é um laboratório onde o material recolhido pelos olhos, ouvidos, etc., é transformado em várias faculdades, como a memória (PAES LOUREIRO, 2007, p. 14). 


\section{míDiA

Esse ato de simbolizar é resultado de heranças culturais, pois "há uma relação intercorrente da criatividade individual com esses conjuntos de valores materiais e espirituais universais que se acumulam no trajeto antropológico do indivíduo e em sua prática histórico-social" (PAES LOUREIRO, 2007, p. 17).

Ao fazer uma análise da história da arte, Paes Loureiro (2007), a compreende como um grande mosaico de conversões semióticas, promovidas por sucessivas transgressões aos padrões vigentes, considerando a metamorfose dos processos e das significações desde a pré-história, passando pela antiguidade clássica, pela idade média até os dias atuais, pressupondo ciclos cada vez mais rápidos e remixados. Conforme o autor, essa conformação assimétrica de mestiçagens, pode ser percebida na transformação das chamadas belas-artes (compreendidas como o ramo erudito da arte) em expressões consideradas banais, a exemplo de Marcel Duchamp ao transformar objetos do cotidiano (como rodas de bicicleta e urinóis) em obra de arte, ou de Andy Warhol ao dar a arte uma faceta publicitária. Também nas inúmeras possibilidades de fazer com que as manifestações artísticas tornem-se procedimentos de alcance popular, como nas performances de rua ou no grafite, por exemplo.

\footnotetext{
A imediatidade e a globalidade atual da informação vêm apagando a chama da concepção linear da evolução artística. Com isso, ocorre o fim da unidade nas belas artes coetânea à avalanche de novos materiais e práticas artísticas, promovendo-se a constelação da heterogeneidade e de "transsemiotização" perene em um mundo dinâmico e heterogêneo. (PAES LOUREIRO, 2007, p. 19)
}

Portanto, Paes Loureiro (2007) sugere que a conversão semiótica é um processo de transfiguração que acompanha a humanidade desde tempos imemoriais, sendo mediação no processo das construções culturais e das significações na arte. Entretanto, torna-se mais perceptível na pós-modernidade, marcada pela pluralidade de estilos e multiplicidade de linguagens e códigos. O mundo contemporâneo agrega a arte como parte do cotidiano, sendo reproduzida industrialmente, misturando tendências, tecnologias, quebrando hierarquias e até mesmo inserindo-se no meio ambiente e transformando espaços públicos e privados.

Além disso, tão importantes quanto as obras são as atitudes e posturas artísticas. O discurso. A individualização de processos, embora, muitas vezes, 
com tendência à banalização. Diante dos novos paradigmas, o processo de conversão semiótica se mantém incólume, uma vez que significa um mundo de mudança na qualidade do signo, independente de época ou tendências, sendo válido tanto no passado como no presente. Porém, ele se torna mais evidente no mundo atual pela densificação do dinamismo das mudanças e, logo, epistemológica e heuristicamente, como um conceito fundamental. Pois é, em si, “multi”. (PAES LOUREIRO, 2007, p. 21)

\section{Corpo, mente, ambiente em processos de criação artística}

Inspiração, técnica, dedicação? Não há fórmulas ou caracterizações definitivas para explicar os processos da criação artística, já que no fluxo desse processo comunicativo há tantas variáveis que a razão se esgota em limites conceituais, dando a essa prática inerente ao homem outras possibilidades de acesso e entendimento.

Ao entrarmos na discussão sobre esse inquietante e dinâmico processo, acreditamos que seja importante termos algumas noções sobre aspectos relativos aos sistemas sensórios e cognitivos do ser humano, e sobre as implicações na relação do corpo, mente, da cultura e da tecnologia com o ambiente, suas inter-relações e interconexões.

Por transacionarmos relações ecossistêmicas entre os campos da comunicação e da arte, temos consciência de que a subjetividade tem um papel marcante no conjunto de influências e significações nessa possibilidade de configuração. Mesmo sem entrarmos em questões profundas da psicologia, filosofia ou da sociologia, cremos que os aspectos subliminares na comunicação articulem as conexões entre códigos de linguagens e de representações estéticas e ideológicas inseridas em diferentes ambientes.

No fluxo intercambiante de memórias mentais e corporais, Sacks (1997) salienta que o cérebro é capaz de criar inúmeras realidades e de se adaptar a elas, por vezes provocando curiosas conexões entre alucinação, memória e realidade, bem como a ativação de talentos artísticos, que podem eclodir a partir de percepções, gestos, deslocamentos no espaço, reflexões pessoais, etc.

Para o físico teórico norte-americano Leonard Mlodinow (2013) é preciso compreender a influência dos instintos inconscientes, abaixo da superfície da mente, que se escondem nos sujeitos, para entender o comportamento social e o mundo ao nosso redor, pois a memória e a imaginação são de extrema importância para a 
construção, compreensão e comunicação em torno do que concebemos por realidade. Para o autor "ao contrário dos fenômenos da física, na vida, os eventos com frequência podem obedecer a uma teoria ou a outra; o que acontece na verdade pode depender muito da teoria em que escolhemos acreditar” (MLODINOW, 2013, p. 258).

A preocupação sobre os processos do pensamento acompanha os filósofos desde a antiguidade, conforme Mlodinow (2013), mas só a partir do século XIX é que os cientistas passaram a dar mais atenção aos estudos envolvendo a fisiologia e a psicologia, tendo como destaque o trabalho do neurologista Sigmund Freud, criador da psicanálise, com as Teorias da Representação, do Processo de Pensamento e da Divisão do Inconsciente. Desde então, os estudos evoluíram e com os progressos da ciência foi possível mapear rotas complexas realizadas pelo cérebro. Estima-se que apenas $5 \%$ de nossas funções cognitivas sejam conscientes, o restante opera de forma inconsciente e exerce influência subliminar em nossos sentimentos, pensamentos e atos (MLODINOW, 2013).

A evolução nos deu uma mente inconsciente porque é ela que permite nossa sobrevivência num mundo que exige assimilação e processamento de energia tão maciços. Percepção sensorial, capacidade de memória, julgamentos, decisões e atividades do dia a dia parecem não exigir esforço - mas isso só porque o esforço demandado é imposto sobretudo a partes do cérebro que funcionam fora do plano da consciência. (MLODINOW, 2013, p. 31)

Segundo Mlodinow (2013) outras espécies animais também apresentam atividades cerebrais em níveis conscientes e inconscientes, mas, no caso da espécie humana a necessidade de interação social foi propulsora para a evolução da inteligência. Conforme o autor, diferente de outras espécies, a capacitação do ser humano para o comportamento social, é decorrente da conformação genética que caracteriza a espécie humana há cerca de 50 mil anos, quando os indivíduos começaram a pescar, caçar e perseguir animais ferozes no intuito de lutar em coletividade pela sobrevivência.

$\mathrm{O}$ autor nos indica que essa transformação começou a conformar as bases da cultura, da complexidade ideológica e cooperação coletiva da sociedade, do mesmo modo que nela podem estar as raízes da arte e a gênese do processo criativo. Contudo, tratar da arte e da criatividade, por si só, é uma tarefa hercúlea, e neste momento vamos discutir apenas alguns aspectos que envolvem processos criativos e comunicativos, 
portanto, nossa abordagem é um pequeno recorte de um universo riquíssimo e que pode ser explorado por diferentes perspectivas.

A percepção estética, por exemplo, pode provocar efeitos reverberados no corpo todo, a partir das sensações captadas pelo entorno, muitas vezes regidas por leis da física, como- a percepção das cores, que está relacionada à ótica (pela interação da luz com a matéria), ou aos sons detectados pelo ouvido que chegam por ondas sonoras e que podem provocar uma série de imagens mentais, conforme Santaella (2001). Todos esses processos perceptivos são codificados em processos fisiológicos, psíquicos e químicos pelo cérebro, seguindo às leis da natureza e posteriormente ressignificados.

Desse modo, percebemos a importância do "corpomente"5 e do ambiente como uma força motriz no ciclo comunicacional e na criação artística. Para Greiner (2005) o corpo não é apenas um recipiente e transmissor de informações, mas um organismo transformador em constante evolução pela contaminação entre o fluxo informacional que percorre seu contexto sensitivo interno e externo. As experiências decorrentes dessas relações geram comunicação, percepção e relação. A autora propõe pensar o corpo como um sistema complexo e interativo e não apenas como um instrumento, com um lado biológico e outro cultural, ou material e mental.

Possivelmente, essa dicotomia tenha explicação na gênese etimológica da palavra corpo, segundo Greiner (2005), ao explicar que, do latim, corpus ou corporis se referem ao corpo morto, em oposição a alma ou ânima que expressa o corpo vivo. A autora aponta evidencias que conectam o processo co-evolutivo do corpo e do ambiente com exemplos de fluxos conectivos entre nações, línguas e culturas, redefinindo os mapas de "fronteiras dramáticas" das "geografias imaginativas". Isso porque o corpo é provido de uma dramaturgia que dá sentido e coerência ao fluxo incessante de informações entre o corpo e o ambiente.

Estamos trabalhando com a ideia de "corpomente" e ambiente, a partir da Teoria Corpomídia, formulada pelas pesquisadoras Christine Greiner e Helena Katz, do Centro de Comunicação das Artes do Corpo, vinculado ao Programa de Pós-Graduação em Comunicação e Semiótica da PUC-SP, que propõe pensar o corpo como um organismo ecológico, ou seja, inseparável da relação com o seu ambiente. Segundo Greiner (2005) o corpo é sujeito físico, mental e ambiental, pois está em permanente processo de evolução com o ambiente natural e cultural em que se insere, contrapondo-se a noção cartesiana na qual corpo, mente e ambiente estão dissociados. 
O modo como ela se organiza em tempo e espaço é também o modo como as imagens do corpo se constroem no trânsito entre o dentro (imagens que não se vê, imagens-pensamentos) e o fora (imagens implementadas em ações) do corpo organizando-se como processos latentes de comunicação. (GREINER, 2005, p. 73)

Em relação à arte, Greiner (2005) diz que o corpo muda cada vez que percebe o mundo, despertando metáforas mutantes que geram novas ações, caracterizando um "corpo artista" a partir da inspiração na hipótese levantada pelo neurocientista Vilayanur Ramaschandran, para quem a arte (como fenômeno mental) teria uma função fundamentalmente necessária para sobrevivermos. "Assim como a atividade sexual e a experiência da morte (próxima ou anunciada), a atividade estética representaria em nosso processo evolutivo, uma ignição para a vida" (GREINER, 2005, p. 111).

Ao buscarmos ampliar as possibilidades de interpretar aspectos relacionados às interconexões comunicacionais, em fluxos criativos na arte, acreditamos ser fundamental a compreensão de Salles (2010 e 2012), pois a autora defende que o artista, por meio de seus filtros e sua sensibilidade, interpreta e representa o mundo à medida em que experimenta determinadas sensações, incorpora percepções do mundo ao seu redor, interage com a memória, reorganiza experiências passadas e permite a fabulação.

Salles (2012) argumenta sobre a importância de analisar os registros materiais dos processos e métodos da produção artística para compreender o percurso criativo dos artistas. Segundo a autora, a arte é uma sequência de agregações de ideias com possibilidades infinitas em permanente mutação - um "gesto inacabado".

É um processo em mobilidade e metamorfose sempre aberto à introdução de novas ideias, no qual todo o processo criativo é um ato comunicativo. A arte carrega as marcas singulares de cada artista, mas é um universo amplo, em construção contínua de uma grande cadeia sistêmica. Assim, "o projeto poético de cada artista insere-se na frisa do tempo da arte, da ciência e da sociedade em geral" (SALLES, 2012, p.42).

$\mathrm{O}$ artista desenvolve seu trabalho a partir de intrincadas relações em rede, criando obras em movimento, conceitualmente abertas e flexíveis, recebendo influências diversas, seja por imagens, relacionamentos, lembranças, fatos marcantes. O ambiente também exerce uma relação complexa e um papel determinante no processo de criação. 
A criação como rede pode ser descrita como um processo contínuo de interconexões instáveis, gerando nós de interação, cuja variabilidade obedece a alguns princípios direcionadores. Essas interconexões envolvem a relação do artista com seu espaço e seu tempo, questões relativas à memória, à percepção, recursos criativos, assim como os diferentes modos que se organizam as tramas do pensamento em criação. (SALLES, 2010, p. 215)

Nesse sentido, Salles (2010) acredita que o processo de criação é uma manifestação comunicacional, ao relacionar o diálogo do artista com ele mesmo e suas ideias, com a materialidade da obra em criação, sua trama de experimentações, com os expectadores, com a crítica, enfim, estabelece um circuito de interlocuções espaçotemporais que vão gerar transformações e ressignificações.

Desse modo, a observação e a sensibilidade são fundamentais para captar os fluxos comunicacionais da arte. É necessário um olhar inter-relacional, porque a ação artística não é linear, tem ritmos, picos, curvas e nós. Uma construção que vai se tramando em processos contínuo de interconexões e interações no tempo e no espaço, através de um percurso singular que "é feito de palavras, imagens, sons, gestualidades etc." (SALLES, 2010, p.102).

Diante disso, ao apresentarmos essa aproximação entre comunicação e arte, procuramos ampliar as possibilidades de reflexão e leitura acerca de objetos e processos da realidade sociocultural, propondo outros olhares frente aos fenômenos que exigem maior plasticidade nas abordagens investigativas e, assim, criando novas perguntas e significados para configurações culturais-artísticas-comunicacionais.

\section{Referências}

CAPRA, Fritjof. As conexões ocultas - ciência para uma vida sustentável. São Paulo: Cultrix, 2002.

COLFERAI, Sandro Adalberto. Um jeito amazônida de ser mundo. A Amazônia como metáfora do ecossistema comunicacional. Tese [Doutorado em Sociedade e Cultura na Amazônia]. Universidade Federal do Amazonas, Programa de Pós-Graduação em Sociedade e Cultura na Amazônia. Manaus: UFAM, 2014.

GREINER, Christine. O corpo, pistas para estudos indisciplinares. São Paulo: Annablume, 2005.

JANSON, Horst. História da Arte. São Paulo: Martins Fontes, 1996.

LITTLEJOHN, Stephen. Fundamentos teóricos da comunicação humana. Rio de Janeiro: Editora Guanabara, 1988. 
MLODINOW, Leonard. Subliminar - Como o inconsciente influencia nossas vidas. Rio de Janeiro: Zahar, 2013.

MONTEIRO, Gilson Vieira; ABBUD, Maria Emília de Oliveira Pereira; PEREIRA, Mirna Feitosa (orgs.). Estudos e perspectivas dos ecossistemas na comunicação. Manaus: Edua/Ufam, 2012.

MORIN, Edgar. Ciência com consciência. Rio de Janeiro: Bertrand, 2010.

PAES LOUREIRO, João. A conversão semiótica: na arte e na cultura. Belém: Edufpa, 2007.

PROUS, André; RIBEIRO, Loredana. Arte Rupestre Pré-histórica: imagens fixas, significados mutáveis. Curitiba: Zencrane, 2007.

SACKS, Oliver. O homem que confundiu sua mulher com um chapéu e outras histórias clínicas. São Paulo: Cia. das Letras, 1997.

SALLES, Cecília Almeida. Gesto inacabado: processo de criação artística. São Paulo: Intermeios, 2012.

Arquivos de Criação: arte e curadoria. São Paulo: FAPESP/ Ed. Horizonte, 2010.

SANTAELLA, Lucia. Culturas e artes do pós-humano: da cultura das mídias à cibercultura. São Paulo: Paulus, 2003.

. Matrizes da linguagem e pensamento: sonora, visual, verbal. São Paulo: Iluminuras/FAPESP, 2001.

O que é semiótica. São Paulo: Brasiliense, 2007.

Semiótica aplicada. São Paulo: Pioneira Thomson Learning, 2005

; NÖTH, Winfried. Imagem, cognição, semiótica e mídia. São Paulo: Iluminuras, 1999. 